\title{
Analisi Kadar ALP (Alkaline Phospatase) Dan Kholinesterase Akibat Lama Bekerja Pada Petugas Fogging Di Kota Denpasar
}

\author{
Ni Kadek Mona Fujiastuti Hendriani*, Ni Putu Rahayu Artini , I Wayan Tanjung Aryasa \\ Program Studi Teknologi Laboratorium Medik \\ Fakultas Ilmu Kesehatan \\ Universitas Bali Internasional \\ Email : fujiastutimona5@gmail.com
}

\begin{abstract}
Tanggal Submit: 24 Agustus 2020

Tanggal Review:

9 November 2020

Tanggal Publish Online:

10 Desember 2020

Fogging is an effective way to prevent dengue fever in Indonesia. The side effects of fogging can have an impact on its officers by being exposed and inhaled by continuing to treat fumes that contain pesticides. So, that the liver function examination is carried out to determine the increase in ALP (Alkaline Phospatase ) levels and decrease in cholinesterase levels due to a long time working on fogging officers in Denpasar. This aims to determine whether there is an increase in ALP levels and a decrease in the level of cholinesterase in fogging officers' blood samples. This type of research carried out statistical tests by displaying the lowest, highest value and average test results and deviations standards. From the examination results obtained, it was found that ALP levels in March 2020 with an average of $63.1 \pm 0.23 \mathrm{IU} / \mathrm{L}$, while in April 2020 with an average of $98.0 \pm 0.23 \mathrm{IU} / \mathrm{L}$, at cholinesterase levels in March 2020 with an average of $5.2 \pm$ $0.01 \mathrm{kU} / \mathrm{L}$, while in April 2020 the average was $6.5 \pm 0.01 \mathrm{kU}$ / L. It can be concluded that there was an increase in ALP with an average percentage increase of $0.88 \%$ and a decrease in cholinesterase levels in April higher than March, with an average percentage decrease of $0.29 \%$.
\end{abstract}

Keywords: duration of work, ALP, fogging, cholinesterase.

\section{PENDAHULUAN}

Penyakit Demam Berdarah

Dengue (DBD) merupakan salah satu penyakit menular dan endemis di Indonesia. Peratama kali penyakit DBD dilaporkan di Jakarta dan Surabaya pada tahun 1968 (Soedarmo, 2015). Salah satu upaya yang dapat dilakukan untuk mengontrol penyebaran penyakit yaitu dengan melakukan pemetaan vektor penyakit tersebut dengan cara fogging (Soedarmo, 2015). Asap yang menguap dari penyemprotan pestisida sangat berbahaya bagi tubuh jika terpapar dan terhirup terus menurus, ini akan menyebabkan terjadinya gangguan pernafasan 
sehingga zat-zat berbahaya bisa menyebabkan terjadinya gangguan fungsi hati (Achmad, 2012).

\section{Sehingga dilakukannya}

pemeriksaan fungsi hati sperti kadar ALP (Alkaline Phospatase) dan kadar kholinesterase akibat lama bekerja pada petugas fogging di Kota Denpasar. Pemeriksaan fungsi hati bertujuan untuk mengetahui ada tidaknya peningkatan kadar ALP dan penurunan kadar kholinesterase dalam darah petugas fogging. Adapun manfaat dari penelitian ini untuk memberi informasi dan wawasan pada pembaca.

$$
\text { ALP merupakan enzim }
$$

hydrolase yang di produksi pertama oleh epitel hati dan osteoblast ( sel-sel pembentuk tulang baru) enzim ini banyak ditemukan di hepar (isoenzim ALP-1) dan tulang (isoenzim ALP-2), serta sedikit diproduksi oleh sel-sel pada saluran pencernaan, plasenta, dan ginjal, nilai normal kadar ALP 30-115 IU/L (Adam, 2011). Sedangkan kholesterol adalah atau disebut dengan enzim asetylkholinesterase merupakan enzim yang terdapat pada cairan seluller, yang fungsinya menghentikan aksi AchE dengan jalan terhidrolisis menjadi cholin dan asam asetat, nilai normal kholesterol adalah 6,20- 11,5 kU/L (Mamangkot, 2013). Adapun hipotesis dalam penelitian ini terdapat kenaikan kadar ALP (Alkali Phospatase) akibat lama bekerja pada petugas fogging di Kota Denpasar dan terdapat penurunan kadar kholinesterase akibat lama bekerja pada petugas fogging di Kota Denpasar.

\section{METODE PENELITIAN}

\section{Bahan dan Peralatan}

Bahan yang digunakan pada penelitian ini terdiri atas sampel dan bahan kimia. Sampel yang digunakan pada penelitian ini adalah darah vena yang diambil sebanyak $4 \mathrm{cc}$, kemudian dipisahkan dengan centrifuge untuk mendapatkan serum yang akan digunakan untuk pemeriksaan ALP dan kholinesterase. Bahan kimia yang digunakan pada penelitian ini berupa reagen ALP dan reagen kholinesterase.

Alat yang digunakan pada penelitian ini terdiri atas alat plebotomi, wadah trasportasi sampel, alat untuk analisis dan alat pendukung. Alat plebotomi terdiri dari jarum vakutainer dan holder, tourniquet, kapas alkohol 70\% (oneswab), plester dan tabung tutup kuning. Wadah untuk trasportasi sampel berupa cool box dan ice gel. Alat untuk analisis terdiri dari seprangkat alat fotometer, centrifuge 
(Eppendorf), mikropipet (Epprndorf) dan tip. Alat pendukung berupa lembar kuesioner yang digunakan untuk memperoleh informasi mengenai identitas dan lam bekerja sebagai petugas fogging.

\section{Prosedur Peneltian}

\section{Pengambilan Darah Vena}

\section{Pemberian kuesioner}

dilakukan sebelum pengambilan sampel darah, dengan tujuan untuk mengetahui identitas dengan lengkap. Prosedur pengambilan darah vena menurut (WHO, 2010) diawali dengan proses perkenalan diri kepada pasien, lalu menanyakan identities pasien secara lengkap. Alat dan bahan disiapkan untuk digunakan pengambilan darah ( jarum, holder, tourniquet, tabung, vakum, kapas alkohol 70\%, plaster), serta penggunaan APD ( jas laboratorium, sarung tangan dan masker) secara lengkap.

Jarum dipasang pada holder dan dipastikan terpasang erat. Vena diperiksa pada lengan pasien, dilakukan pemasangan tourniquet sekitar 4-5 lebar jari di atas vena. Vena lalu dibersihkan dengan kapas alkohol $70 \%$ dengan arah pembersihan dimulai dari bagian dalam ke luar, dibiarkan mengering sepenuhnya dan kemudian ditusuk bagian vena dengan posisi lubang jarum menghadap ke atas. Tabung dimasukkan ke dalam holder dan didorong sehingga jarum bagian posterior tertancap pada tabung, maka darah akan mengalir masuk kedalam tabung. Ditunggu sampai darah berhenti mengalir. Setelah itu, dilepaskan tourniquet terlebih dahulu baru kemudian ditarik jarum secara perlahan dan diberikan sedikit tekanan pada vena yang ditusuk dengan kapas kering, kemudian diberikan plaster. Terahir diberi label (Identitas pasien, jenis pemeriksaan) pada tabung vakum.

\section{Pemisahan Serum}

Prosedur pemisahan serum adalah sampel darah yang telah didapat ditunggu hingga membeku. Setelah darah membeku, dimasukkan ke dalam centrifuge untuk dilakukan pemisahan. Posisi tabung darah di dalam centrifuge diatur sedemikian rupa dengan posisi seimbang dan diputar dengan kecepatan 3000 rpm selama 10 menit. Serum yang terbentuk kemudian dipisahkan dari darah untuk dilakukan pemeriksaan. Jika tidak langsung dilakukan pemeriksaan, serum dapat disimpan pada refrigerator dengan suhu $2^{\circ}$ $10^{\circ} \mathrm{C}$ atau pada freezer dengan suhu $20^{\circ} \mathrm{C}$ (Abbott, 2017). 
Pemeriksaan ALP dengan

Fotometer

Pemeriksaan ALP dilakukan dengan alat fotometer dengan merek mindray dan dibaca pada panjang gelombang $405 \mathrm{~nm}$. Serum dipipet sebanyak 20ul ke dalam wadah sampel dan di tambahkan reagen latex sebanyak 1000ul, lalu diinkubasi tiga menit pada suhu ruang. Kemudian dibaca dengan alat fotometer, ditunggu dua menit kadar ALP akan muncul pada alat fotometer, lalu dihitung persentase kenaikan kadar ALP dengan menggunakan rumus (Mindray, 2016).

\section{Pemeriksaan}

Kholinesterase

\section{dengan Fotometer}

Pemeriksaan kholinesterase dilakukan dengan alat fotometer dengan merek mindray dan dibaca pada panjang gelombang $405 \mathrm{~nm}$. Serum dipipet sebanyak 20ul kedalam wadah sampel lalu ditambahkan reagen latex satu sebanyak 100ul, diinkubasi selama tiga menit, ditambahkan reagen latex dua sebanyak 250ul. Baca pada fotometer, di tunggu dua menit kadar kholinesterase akan muncul pada alat fotometer, lalu dihitung persentase penurunan kadar kholinesterase dengan menggunakan rumus

(Mindray, 2016).

\section{Analisis Data}

Pada penelitian ini dilakukan analisis data dengan data yang diperoleh dari hasil pemeriksaan dilakukan uji statistik dengan menampilkan nilai terendah, tertinggi, rata-rata hasil pengujian dan standar deviasi untuk mengkoreksi kesalahan dalam proses analisis. Data yang diperoleh dari kuesioner disajikan dalam bentuk tabel dan dilakukan penjabaran karateristik responden berupa umur, jenis kelamin, pola makan, gaya hidup dan aktifitas fisik.

\section{HASIL}

Pada penelitian ini diporeh data karateristik responden pada petugas fogging di Kota Denpasar. Hasil data karateristik responden disajikan pada Tabel 1. 
Tabel 1. Hasil Karateristik Responden Pada Petugas Fogging Di Kota Denpasar

\begin{tabular}{|c|c|c|}
\hline \multicolumn{2}{|c|}{ Parameter kuesioner } & Jumlah \\
\hline Usia & $\begin{array}{l}<20 \text { tahun } \\
20-30 \text { tahun } \\
>30 \text { tahun }\end{array}$ & $\begin{array}{r}3 \text { orang } \\
15 \text { orang } \\
12 \text { orang }\end{array}$ \\
\hline Jenis kelamin & Laki -Laki & 30 orang \\
\hline Lama bekerja & $\begin{array}{l}1-3 \text { tahun } \\
4-6 \text { tahun } \\
7-10 \text { tahun }\end{array}$ & $\begin{array}{r}5 \text { orang } \\
12 \text { orang } \\
13 \text { orang }\end{array}$ \\
\hline Frekuensi fogging & $\begin{array}{l}1 \mathrm{x} \text { sehari } \\
2 \mathrm{x} \text { sehari } \\
3 \mathrm{x} \text { sehari } \\
>3 \mathrm{x} \text { sehari }\end{array}$ & $\begin{array}{l}3 \text { orang } \\
6 \text { orang } \\
12 \text { orang } \\
9 \text { orang }\end{array}$ \\
\hline Merokok & $\begin{array}{l}\text { Iya } \\
\text { Tidak }\end{array}$ & $\begin{array}{l}20 \text { orang } \\
10 \text { orang }\end{array}$ \\
\hline Minuman beralkohol & $\begin{array}{l}\text { Konsumsi } \\
\text { Tidak konsumsi }\end{array}$ & $\begin{array}{l}12 \text { orang } \\
18 \text { orang }\end{array}$ \\
\hline Pemeriksaan kesehatan & $\begin{array}{l}\text { Pernah } \\
\text { Tidak pernah }\end{array}$ & $\begin{array}{l}10 \text { orang } \\
20 \text { orang }\end{array}$ \\
\hline Riwayat penyakit & $\begin{array}{l}\text { Ada } \\
\text { Tidak ada }\end{array}$ & 30 orang \\
\hline
\end{tabular}

Hasil pemeriksaan kadar ALP dan kholinesterase pada petugas fogging pada bulan Maret dan April disajikan pada Tabel 2 dan Tabel 3.

Tabel 2. Hasil Pemeriksaan kadar ALP pada petugas fogging di Kota Denpasar

\begin{tabular}{lcccc}
\hline \multirow{2}{*}{ Bulan } & $\begin{array}{c}\text { Nilai } \\
\text { Rujukan } \\
(\mathbf{I U} / \mathbf{L})\end{array}$ & Terendah & Tertinggi & Rata-rata \\
\cline { 3 - 5 } & \multirow{2}{*}{ Maret } & $20,0 \pm 0,00$ & $98,0 \pm 0,00$ & $63,1 \pm 0,23$ \\
April & $30-115$ & $60,0 \pm 0,00$ & $158,0 \pm 0,00$ & $98,0 \pm 0,23$ \\
\hline
\end{tabular}

Hasil kadar ALP berdasarkan table diatas, rata - rata ALP akibat lama bekerja pada petugas fogging pada bulan Maret terendah sebesar 20,0 $\pm 0,00 \mathrm{IU} / \mathrm{L}$, kadar tertinggi sebesar $98,0 \pm 0,00 \mathrm{IU} / \mathrm{L}$, dengan rata-rata sebesar 63,1 \pm 0,23 IU/L. Hasil kadar ALP akibat lama bekerja pada bulan April terendah sebesar $60,0 \pm 0,00$ IU/L, kadar tertinggi sebesar 158,0 $\pm 0,00 \mathrm{IU} / \mathrm{L}$, dengan rata-rata sebesar $98,0 \pm 0,23 \mathrm{IU} / \mathrm{L}$. 
Tabel 3. Hasil pemeriksaan kadar kholinesterase pada petugas fogging di Kota Denpasar.

\begin{tabular}{llcccc}
\hline No & Bulan & $\begin{array}{c}\text { Nilai } \\
\text { Rujukan } \\
\text { kU/L }\end{array}$ & \multicolumn{2}{c}{ Kadar Kholinesterase $(\mathbf{k U} / \mathbf{L})$} \\
\cline { 4 - 6 } & & Terendah & Tertinggi & Rata-rata \\
\hline 1 & Maret & \multirow{2}{*}{$6.20-11.5$} & $3,2 \pm 0,05$ & $7,0 \pm 0,05$ & $5,2 \pm 0,01$ \\
2 & April & & $5,0 \pm 0,00$ & $9,6 \pm 0,00$ & $6,5 \pm 0,01$ \\
\hline
\end{tabular}

Berdasarkan tabel diatas, hasil rata-rata kadar kholinesterase akibat lama bekerja petugas fogging pada bulan Maret terendah sebesar 3,2 $\pm 0,05$ $\mathrm{kU} / \mathrm{L}$, kadar tertinggi sebesar 7,0 $\pm 0,05$ $\mathrm{kU} / \mathrm{L}$, dengan rata-rata sebesar $5,2 \pm$ 0,01 kU/L. Hasil kadar Kholinesterase akibat lama bekerja pada bulan April

Tabel 4. Hasil Persentase Kenaikan Kadar ALP Dan Penurunan Kadar Kholinesterase Di Kota Denpasar.

\begin{tabular}{cc}
\hline Kadar ALP & \% rata- rata kenaikan \\
\hline ALP & $0,88 \%$ \\
\hline Kadar Kholinesterase & \% rata-rata penurunan \\
\hline Kholinesterase & $0,29 \%$ \\
\hline
\end{tabular}
kadar rata-rata peningkatan sebesar

\section{PEMBAHASAN}

Berdasarkan tabel karateristik responden, sebanyak 30 petugas fogging di Kota Denpasar bersedia menjadi sampel penelitian. Dari 30 orang petugas terendah sebesar 5,0 $\pm 0,00 \mathrm{kU} / \mathrm{L}$, kadar tertinggi sebesar $9,6 \pm 0,00 \mathrm{kU} / \mathrm{L}$, dengan rata-rata sebesar $6,5 \pm 0,01$ kU/L. Berdasarkan hasil perhitungan persentase kenaikan kadar ALP dan penurunan kadar kholinesterase pada petugas fogging disajikan pada Tabel 4.

\begin{abstract}
Berdasarkan dari hasil presentase diatas, dari 30 petugas fogging terdapat enam orang dengan persentase kadar ALP tinggi, dengan

$0,88 \%$. Sedangkan persentase kadar kholinesterase terdapat empat orang mengalami penurunan, dengan rata-rata penurunanan sebesar $0,29 \%$.
\end{abstract}


laki-laki, lima orang dengan lama bekerja satu sampai tiga tahun, 12 orang dengan lama bekerja empat sampai enam tahun dan 13 orang dengan lama bekerja 7-10 tahun. Dalam melakukan fogging tiga orang melakukan fogging satu kali sehari, enam hari orang melakukan fogging dua kali sehari, 12 orang melakukan fogging tiga kali sehari dan sembilan orang melakukan fogging lebih dari tiga kali sehari. Dari semua petugas fogging, 20 orang merokok dan 10 orang tidak merokok, kemudian 12 orang mengonsumsi minuman beralkohol dan 18 orang tidak mengonsumsi minuman beralkohol, 10 orang pernah melakukan pemeriksaan kesehatan dan 20 orang tidak pernah melakukan pemeriksaan kesehatan dan dari semua orang petugas fogging semua tidak memiliki riwayat penyakit.

Terjadinya peningkatan kadar ALP dan penurunan kadar kholinesterase akibat lama bekerja pada petugas fogging disebabkan karena terpaparannya pestisida dengan terus menerus sehingga mengakibatkan keracunan pestisida melalui mulut dapat terjadi karena beberapa hal antara lain makan, minum dan merokok ketika bekerja dengan pestisida. Pestisida masuk melalui kulit dapat terjadi ketika mengelap keringat dengan tangan, lengan baju atau sarung tangan yang terkontaminasi pestisida. Kontaminasi dapat terjadi karena tidak memakai APD lengkap antara lain masker, baju lengan panjang, celana panjang, topi, kaca mata, kaos tangan dan sepatu boots (Isnawan. 2013). Pestisida yang terakumulasi dalam jangka panjang akan menimbulkan kerusakan pada organ tubuh yang menjadi target bahan kimia pestisida tersebut seperti hati, ginjal, dan paru (Siwiendrayanti. 2012).

Berdasarkan hasil penelitian kadar ALP dan kadar kholinesterase akibat lama bekerja pada petugas fogging di Kota Denpasar menunjukkan bahwa terjadi kenaikan kadar ALP dan penurunan kadar Kholinesterase pada darah. Kenaikan kadar ALP dapat meningkat disebabkan oleh beberapa makanan seperti kerang laut, daging sapi, daging ayam, susu, dan makanan berlemak tinggi dan minyak, seperti minyak kelapa dan minyak jagung (Mamangkot, 2013). Upaya pencegahan lain dapat berupa menerapkan gaya hidup lebih sehat, seperti mengkonsumsi makanan bergizi seimbang, hindari mengkonsumsi minuman beralkohol, hindari rokok, melakukan aktifitas fisik atau olahraga dan melakukan pola diet dengan konsultasi terhadap dokter dan ahli gizi agar kadar ALP dan Kholinesterase kembali membaik (Sasmito, 2016). 


\section{SIMPULAN}

1. Pada penelitian ini terdapat peningkatan kadar ALP akibat lama bekerja pada petugas fogging di Kota Denpasar pada bulan Maret tahun 2020 dan bulan April tahun 2020, dimana kadar ALP bulan April lebih tinggi dari bulan Maret, dengan rata-rata persentase kenaikan sebesar $0,88 \%$.

2. Pada penelitian ini terdapat penurunan kadar kholinesterase akibat lama bekerja pada petugas fogging di Kota Denpasar pada bulan Maret tahun 2020 dan bulan April tahun 2020, dimana kadar kholinesterase bulan April lebih tinggi dari bulan Maret, dengan rata-rata persentase penurunan sebesar $0,29 \%$.

\section{DAFTAR PUSTAKA}

Abbott. 2017. Clinical Fotometer Learning Guide Series. Ebook available on abbottdiagnostics.com

Achmadi. U. F. 2012. Dasar-Dasar Penyakit Berbasis Lingkungan. Jakarta : Rajawali Pers

Adam. JM. 2011. Buku Ajaran Ilmu Penyakit Dalam Jilid III Edisi $V$. Jakarta. Balai Penerbit. FKUI.
Isnawan. 2013. Kandungan Enzim Kholinesterase dan Icreatendi pada Petani Penebar Pestisida di Kabupaten Brebes. Majalah Farmasi Indonesia.

Mamangkot, 2013. Gambaran aktivitas cholinesterase pada petani sayuran di kelurahan kalampangan kota palangkaraya. Universitas Palanga Raya.

Mindray. 2016. Indiko TM Plus Clinical and Specialty Fotometer System.

Mindray. 2016. Insert Kit ALP-Alkaline Phospatase and Cholinesterase Plus.

Sasmito. 2016. Kandungan Enzim Kholinesterase dan Icreatendi pada Petani Penebar Pestisida di Kabupaten Brebes. Majalah Farmasi Indonesia 1996, 7 (2) : 55-56.

Siwiendrayanti, 2012. Kajian Keracunan Pestisida Pada Petani Penyemprot Cabe di Desa Candi Kecamatan Bandungan Kabupaten Semarang. Tesis. Universitas Diponegoro.

Soedarmo. S. S. P. 2015. Demam Berdarah (Dengue) pada Anak. Jakarta : UIPress.

WHO. 2010. WHO Guidelines on Drawing Blood : Best Practices in Phlebotomy.WHO Library Cataloguing in Publication Data 